\title{
The Effectiveness of Small Side Games (SSG) in Forearm Pass Volleyball Use Application in Mobile Phone
}

\author{
Desy Tya Maya Ningrum ${ }^{1, *}$, James Tangkudung ${ }^{1}, J_{0 h a n s y a h ~ L u b i s}{ }^{1}$, Ade Ros Riza $^{2}$, \\ Eskar Tri Denatara ${ }^{3}$ \\ ${ }^{1}$ Department of Physical Education, Universitas Negeri Jakarta, Indonesia \\ ${ }^{2}$ Department of Physical Education, Health and Recreation, Universitas Negeri Medan, Indonesia \\ ${ }^{3}$ Department of Sports Coaching Education, Universitas Bhayangkara Jakarta Raya, Indonesia
}

Received March 26, 2021; Revised May 6, 2021; Accepted May 30, 2021

\section{Cite This Paper in the following Citation Styles}

(a): [1] Desy Tya Maya Ningrum, James Tangkudung, Johansyah Lubis, Ade Ros Riza, Eskar Tri Denatara, "The Effectiveness of Small Side Games (SSG) in Forearm Pass Volleyball Use Application in Mobile Phone," International Journal of Human Movement and Sports Sciences, Vol. 9, No. 4, pp. 642 - 647, 2021. DOI: 10.13189/saj.2021.090406.

(b): Desy Tya Maya Ningrum, James Tangkudung, Johansyah Lubis, Ade Ros Riza, Eskar Tri Denatara (2021). The Effectiveness of Small Side Games (SSG) in Forearm Pass Volleyball Use Application in Mobile Phone. International Journal of Human Movement and Sports Sciences, 9(4), 642 - 647. DOI: 10.13189/saj.2021.090406.

Copyright $\mathrm{C} 2021$ by authors, all rights reserved. Authors agree that this article remains permanently open access under the terms of the Creative Commons Attribution License 4.0 International License

\begin{abstract}
The learning model used is based on the material provided and adapted to the situation and conditions in the field. There needs to be a game modification so that students can actively participate in learning volleyball games. The purpose of this study was to see the effectiveness of the small side games learning model on the mobile phone application to increase student participation in physical education. The research method used was an experiment with a control group. Participants involved in the study were 84 , subjects in the experimental group are 42 (26 male and 16 female), subjects in the control group are 42 (17 male and 28 female). Instrument in this study include: observation, questionnaire, and forearm pass test. Data analysis used in this study using Excel 2019 by testing the difference in mean (t-test). Number of active students during physical education learning in the control group is 28 students and inactive 14 students. The number of active students during physical education learning in the experimental group was 37 students and 5 students inactive. The results of the effectiveness test show that the learning model of small side games is better for improving volleyball forearm pass skills with the results obtained for $\mathrm{t}_{0} 7.884$ and $\mathrm{t}_{\text {table }} 1.292$ $\mathrm{db} 82$ and $\alpha=0.05$. Although this study only focuses on learning basic skills forearm pass volleyball in high schools
\end{abstract}

and there is no control during the effectiveness test, it can be concluded that this application in mobile learning based small side game forearm pass volleyball can be used to increase participation and basic skills of volleyball. Besides, it's easier for teachers or students to receive material either face-to-face or long distance. This study highlights the benefits of SSG because the mobile learning application contributes to the teacher in making lesson plans and as pupils study guide application for implementing small side games in physical education.

Keywords Forearm Pass Volleyball, SSG (Small Side Games), Mobile Learning

\section{Introduction}

Schools are formal educational institutions in society that are programmed systematically and continuously. With the implementation of the education system in a sustainable manner, the goal of the intellectual life of the nation and state will be achieved later. The success of education is directly proportional to the teaching and learning process applied by the teacher. The learning 
process is a reciprocal relationship between teacher and students to obtain information and knowledge. Technology plays an active role to facilitate the implementation of learning in schools. That the learning theory underpinning the alternative approach is operationalised in a research-informed pedagogical learning design that facilitates students' perceptions of the effectiveness of the approach through experiencing and or observing it working [1].

Technology has a very important role in the educational process and helps to provide direction in the development of the world in education. In the history of educational development, technology was part of the media used to conveyed messages of knowledge to the general public. Recognizing that change will bring challenges and through incorporating the opinion of pupils, as the learners, we can truly strive to understand how technology can be used effectively within physical education [2].

Learning resources in education are starting from, such as books, articles and electronic-based learning resources such as audio, video, internet, and smartphones. The function of learning with media, the use of digital media in physical education also mean that students learn something about media, for example when the use of media generates personal data that the students and teachers work with [3]. Learning to use videos can increase student's interest in learning new things [4]. The teacher felt that the students demonstrated a greater depth of knowledge about throwing and catching skills as a direct result of the use of technology [5].

Technology can also support learning activities, invite community participation and can help people for learning better. Mobile apps may have the potential to encourage participation in physical activity, a careful selection of mobile app functions is required to engage adolescent girls to continue to use it for physical activity [6]. Student-center digital technology approach created a positive learning environment that led to optimal values of intrinsic motivation and academic achievement in physical education pre-service teachers (PSTs) [7]. Type to examine the impact of app-integrated Physical Education on children's social cognitive theory-related beliefs [8].

Although at this time technology can be used in learning, teachers have not been able to make good use of it. Basic skills in volleyball games are only delivered directly to students during face-to-face learning. Even though by utilizing information technology it can be shared quickly and students can also learn it first outside of school. The teachers were motivated to use digital game design principles to provide students with means to solve problems, manage learning motivations, evaluate progress, and gain control over their learning in ways that are not normally associated with the common PE method [9]. Game-play development and the transfer of tactical solutions and decision-making processes across games within the same category were critically and differentially influenced by various situational constraints [10]. The age of the players could be linked with the physical demands within small-sided games [11]. That teachers need to plan specific social skills, such as listening, working together and providing appropriate feedback to each other, to prepare students to work together [12].

The model's processes are designed to capture their creative processes and to make them manifest in the form of an invented game [13]. Teacher engagement in a learning community was paramount to these teachers' development of effective practice when designing and teaching a models-based curriculum enhanced by digital technology (DT) [14]. Technology enormously improve teaching and learning in the field of physical education and sports [15]. The teaching of volleyball courses must break through the shackles of traditional teaching mode, fully utilize the online and offline mixed teaching, and highlight the characteristics of students' individualized learning [16]. Peak locomotor intensity can be modulated during small-sided games (SSGs) of various formats and durations to either overload or underload match demands, with $4 \mathrm{v} 4$ placing the greatest and the least emphasis on MechW and HS, respectively [17]. Game-based conditioning using SSG has become a popular method of developing specific aerobic fitness [18]. Previous several studies have discussed small side games which explain the game of football, no one has discussed the game of volleyball. Besides that, the small side game can also physically require a player to continue move actively during the game. In this study, we wanted to know the effect of small side games on volleyball games made in the mobile phone application so that students know the physical activities that will be carried out first. After that they can immediately apply this game in their next lesson.

\section{Method}

This study used an experimental design with a control group. Participants involved in the study were 84, 42 subjects in the experimental group (26 male and 16 female), 42 subjects in the control group ( 17 male and 28 female), the sample is determined by a random sampling. This research was conducted for 10 meetings within 8 weeks. Students saw the kind of games presented in the mobile phone application first. The teacher divides the teams, explains the rules of the game, chooses opponents, and explains how to play. The teacher also observes the changes that occur during the implementation of small side game volleyball learning by seeing the increase in forearm pass skills and student participation. This experimental research design will be shown in the table below. 
Table 1. Design Experimental

\begin{tabular}{cccc}
\hline Participants & Pre-test & Treatment & Post-test \\
\hline $\mathrm{R}$ & $\mathrm{O}_{1}$ & $\mathrm{X}$ & $\mathrm{O}_{2}$ \\
$\mathrm{R}$ & $\mathrm{O}_{1}$ & - & $\mathrm{O}_{2}$ \\
\hline
\end{tabular}

The observation instrument is used to see the activeness of students during the learning process. The questionnaire was used to evaluate and get suggestion of physical education and sports learning experts and volleyball game experts what the small side game learning model was feasible to use for testing? Observation data can also explain the weakness and preparations that the teacher must make in implementing the small side game learning model. The test instruments for forearm skills include: swinging the arm (from bottom to top the shoulder), one leg in front, the ball bouncing like a parabola, pupils can move the ball to the other field.

To find out the skills of forearm pass volleyball, the researchers conducted a skill test (pre-test) and a final test (post-test). The goal was to conduct the experiment in a non-manipulated (intact) educational context. It followed a pre-test, post-test, experimental, non-equivalent group design [19]. The effectiveness of the model is to carry out the effectiveness test of the model small side games in volleyball. This effectiveness test was carried out by involving high school students, amounting to 84 subjects using a pretest-posttest control group design, the experimental group consisting of 42 subjects and the control group consisting of 42 subjects chosen randomly. By comparing the results of the forearm pass volleyball in the experiment group and the control group it will be known the effectiveness of the small side games model in physical education.

\section{Results}

Validation of physical education learning experts to find out whether the small side game model can be used for teaching learning. Based on the validation data of Physical Education learning experts, the overall learning model small side games of volleyball based on application in mobile learning obtained a percentage of $74.55 \%$. There are a number of inputs obtained including: 1) adding frequency to each learning model when conducting the activity process, 2) the learning model is arranged from the easiest to the one that has a high level of difficulty, (3) the learning steps are clarified in each learning model.

Based on the data validation of volleyball game experts that the small side games learning model based on mobile learning as a whole gained a percentage of $80.10 \%$. There are a number of inputs obtained including: 1) the use of facilities and infrastructure in each model adapted to the need to improve the basic techniques of lower passing and upper passing, 2) the learning model is arranged from the easiest to those that have a high level of difficulty.

Based on the data validation of learning media experts that the mobile learning as a whole gained a percentage of $85.11 \%$. There are some inputs obtained including: 1) clarifying the description of the implementation of each learning model, (2) the picture of the learning model is made more interesting and clearer, 3) the learning video needs to be added to the implementation description.

Based on data observation teaching learning shows that there are some inputs including: 1) before applying the learning model of students must be given clear instructions so that errors do not occur during implementation, 2) in the implementation of student learning must always focus on basic skill of forearm pass volleyball, 3) the need for planning the size of the field and the number of balls at the time of learning, 4) applying the learning model from easy to difficult in accordance with the Learning Program Plan. The implementation of large group trials will be applied to students High Schools. In this study the two groups (experiment and control) had significant differences in results. These results can be seen from student participation during physical education learning and forearm pass skills in volleyball. The findings in this study are shown in the table below.

Table 2. Active and Inactive Small Side Games in Physical Education

\begin{tabular}{|c|c|c|c|}
\hline Group & Active & Inactive & Total \\
\hline Control & 28 & 14 & 42 \\
Experiment & 37 & 5 & 42 \\
\hline
\end{tabular}

From the data above Table 2, it is known that the number of active students during physical education learning in the control group is 28 students or $66,66 \%$ and inactive 14 students or $33,33 \%$. The number of active students during physical education learning in the experimental group was 37 students or $88,09 \%$ and 5 students inactive or $11,90 \%$. Based on post-test data Table 3, from the control group the mean was 69.90 and SD 5,72. The volleyball post-test forearm pass score that obtained the largest percentage was in the $3 \mathrm{rd}$ interval a value of $68-71$ by 9 students or $24,32 \%$ the smallest percentage in the 6th interval with a value of $80-83$ by 3 students or $8,11 \%$. In the control group there was a barely improvement in forearm pass of volleyball because students have basic skills before.

Based on post-test data Table 4, from the experimental group the mean was 79.81 and SD 5,79. The volleyball post-test passing value that obtained the largest percentage was in the 2nd interval with a value of $75-79$ by 17 students or $40,48 \%$. The smallest percentage in the 5 th interval with a value of 4.76 by 2 students or $4,76 \%$. In the experimental group there was a greater increase in forearm pass skills of volleyball due to increased student participation. In addition, students can also choose an easy game first before trying a more difficult game. The 
teacher also provides direct instructions to students if there are errors when practicing of motion. Based on the mean difference final post-test Table 5, in the control and experimental group, it was obtained $t_{0}$ of 7.884 and $t_{\text {table }}$ 1.292 with 82 degrees of freedom and $\alpha=0.05$. Thus, $\mathrm{t}_{0}=$ $7,884>t$ table $=1.292$ that means there are differences in the final test of volleyball passing skills to students after practicing small side games (SSG) with a mobile phone application guide.

Table 3. Control Group Post-Test Forearm Pass Values

\begin{tabular}{cccc}
\hline No & Score & FA & FR (\%) \\
\hline 1 & $60-63$ & 5 & 13,51 \\
2 & $64-67$ & 8 & 21,62 \\
3 & $68-71$ & 9 & 24,32 \\
4 & $72-75$ & 8 & 21,62 \\
5 & $76-79$ & 4 & 10,81 \\
6 & $80-83$ & 3 & 8,11 \\
& Total & 37 & 100 \\
& Mean & 69,90 & \\
& SD & 5,72 & \\
\hline
\end{tabular}

Table 4. Experimental Group Post-Test Forearm Pass Values

\begin{tabular}{cccc}
\hline No & Score & FA & FR (\%) \\
\hline 1 & $70-74$ & 7 & 16,67 \\
2 & $75-79$ & 17 & 40,48 \\
3 & $80-84$ & 12 & 28,57 \\
4 & $85-89$ & 4 & 9,52 \\
5 & $90-94$ & 2 & 4,76 \\
& Total & 42 & 100,00 \\
& Mean & 79,81 & \\
& SD & 5,79 & \\
\hline
\end{tabular}

Table 5. Experimental and Control Group Mean Difference Test Results

\begin{tabular}{cccc}
\hline Sample & $\mathbf{d k}$ & $\mathbf{t}_{\text {count }}$ & $\mathbf{t}_{\text {table }} \boldsymbol{\alpha}=\mathbf{0 , 0 5}$ \\
84 & 82 & 7,884 & 1,292 \\
\hline
\end{tabular}

Based on the results of this study, it was stated that student participation increased during the implementation of the small side game model. Each session begins with the initial game presented in the mobile phone application followed by observations and questions and answers by the Teacher. Examples of sessions about games conducted by students following the applied teaching approach: (a) warm-up; (b) skills training; (c) modified game; (d) games.

The following section presents the results which evaluate the three purposes of the study: (a) to evaluate the 'practice-referenced approach'; (b) test the robustness of the SSG (small side game); and (c) assess how 'alignment of practice' contributes to the development of forearm pass volleyball performance and involvement. The first section of the results will focus on purposes evaluating the 'practice-referenced approach' and examining the robustness of the SSG. This first section will solely consider the results of the individual skills performance behaviours directly associated with the small side games components.

\section{Discussion}

At these meetings 1 and 2, the teacher explains the basic skills forearm pass of volleyball and provides application (mobile learning). The teacher also makes a decision to determine the field size of $5 \times 10$ meters, in one game the number of points is 15 . After that, set the allocation of time, divide the group, deliver the rules of the game in physical education learning. The 3 rd to 10 th meetings students immediately practice learning small side games volleyball were 3 vs 3,4 vs 4 and 5 vs 5 . Students better understand the rules of the game, cooperate with each other, there is motivation from within students to take part in learning. With the modified field and rules of the game can increase student participation in learning and forearm pass volleyball.

Results showed that students who experienced the SSG (small side games) had significantly higher light and moderate physical education activity levels, friendship-approach and friendship-avoidance goals. There are deficiencies in learning model small side games forearm pass volleyball based on mobile learning : 1) make a chart or formation of each games models in order to clarify drawings and instructions, 2) add the frequency of activities to each learning games model when pupils were doing activities, 3 ) learn games models are arranged from the easiest to the most difficult, 4) rules of the game must be clear and easy to implement, 5) these images are made more attractive and clearer, 6) video implementation of learning activities must have voice instructions. Opportunity to reflect on the application of specialized skills in games and suggest strategies for improvement [20].

The result of this research is the model small side games learning forearm pass volleyball based in mobile learning for high school which is considered capable of improving students' skills and knowledge. Effective use of the model requires students to be taught and to possess in-depth content knowledge of the game(s)/activities being taught and learned [21]. Game-centered pedagogy delivered via a teacher professional learning program was efficacious in simultaneously improving students' FMS skills, in-class PA and their decision making and support skills in game play [22]. Basic motion models based on traditional games for early childhood (5-6) years old can be applied as well as effective basic motion models to 
increase activities, abilities and skills through movement [23]. The modern smartphone provides access to screen use but also has features which enable it to promote physical activity [24]. Students are always actively in every lesson given by the teacher because they can learn each activity and determine activities in an application. Active games will inspire students to take part in learning. In the alternative games unit provided Physical Education Teacher Education (PETE) students with the knowledge, understanding and belief in an alternative approach to teaching games compatible with curriculum documents [25].

This study only discusses the basic skills of forearm pass volleyball in senior high school. The teacher needs to know the skills of serve and forearm pass first before implementing the small side game because of students have different skills. In every game students must participate actively. In the future, that other research will discuss teacher planning that explains the learning stages of each meeting so that it will be known the deficiencies of each learning implementation consisting of student cooperation, at what meetings the student's skills improve, and adding other skills to the volleyball game. The contribution of the mobile learning application at the small side game stage through structured planning starting from group division, pupils saw and applied the small side games model 3 vs 3 , 4 vs 4 and, 5 vs 5 , pupils can learn independently through the application. So that this application can be applied to physical education learning in high schools. Teacher educators to reform their teacher preparation programs in ways to facilitate pre-service teachers elementary content knowledge acquisition necessary for successful teaching [26].

\section{Conclusion}

Based on the results of expert validation, and effectiveness tests as well as the discussion that has been made in this study states that mobile learning which presents the kind of games is feasible and effective for use in physical education learning. In each game students can participate actively and students' skills also increase because of the frequency and intensity of motion that is carried out repeatedly. Small side game also showed the spirit to compete in students, learning becomes more interesting with the support of other students. Although in the implementation of learning model small side games there are still weakness because different basic skills of students, but overall, they can choose activities that suit their abilities. Students feel happy with the learning activities were given by the teacher because they can improve skills and knowledge about volleyball. Teachers have not applied the small side game learning model before to students. In the future, it is hoped that the same research will emerge but discuss different types of games.

\section{Acknowledgments}

Thank you to all students and teachers involved in this research and researchers who support each other and provide information about the research findings. It is hoped that similar research on the game of volleyball so that it will strengthen the results of this study.

\section{REFERENCES}

[1] B. Moy, I. Renshaw, K. Davids, and E. Brymer, "Overcoming acculturation: physical education recruits' experiences of an alternative pedagogical approach to games teaching," Phys. Educ. Sport Pedagog., vol. 21, no. 4, pp 386-406, Jul. 2016, doi: 10.1080/17408989.2015.1017455.

[2] H. Bodsworth and V. A. Goodyear, "Barriers and facilitators to using digital technologies in the Cooperative Learning model in physical education," Phys. Educ. Sport Pedagog., vol. 22, no. 6, pp. 563-579, Nov. 2017, doi: 10.1080/17408989.2017.1294672.

[3] S. Greve, M. Thumel, F. Jastrow, C. Krieger, A. Schwedler, and J. Süßenbach, "The use of digital media in primary school PE - student perspectives on product-oriented ways of lesson staging," Phys. Educ. Sport Pedagog., pp. 1-16, Nov. 2020, doi: 10.1080/17408989.2020.1849597.

[4] W. M. H. Bin Sulaiman et al., "Quickly understanding on progressive muscle relaxation with video-based learning in secondary school students," Int. J. Hum. Mov. Sport. Sci., vol. 8, no. 5, pp. 181-185, 2020, doi: 10.13189/saj.2020.080504.

[5] A. Casey and B. Jones, "Using digital technology to enhance student engagement in physical education," Asia-Pacific $J$. Heal. Sport Phys. Educ., vol. 2, no. 2, pp. 51-66, 2011, doi: 10.1080/18377122.2011.9730351.

[6] M. L. C. Seah and K. T. Koh, "The efficacy of using mobile applications in changing adolescent girls' physical activity behaviour during weekends," Eur. Phys. Educ. Rev., vol. 27, no. 1, pp. 113-131, Feb. 2021, doi: 10.1177/1356336X2093 0741 .

[7] A. Calderón, L. Meroño, and A. MacPhail, "A student-centred digital technology approach: The relationship between intrinsic motivation, learning climate and academic achievement of physical education pre-service teachers," Eur. Phys. Educ. Rev., vol. 26, no. 1, pp. 241-262, Feb. 2020, doi: 10.1177/1356336X19850852.

[8] J. E. Lee and Z. Gao, "Effects of the iPad and mobile application-integrated physical education on children's physical activity and psychosocial beliefs," Phys. Educ. Sport Pedagog., vol. 25, no. 6, pp. 567-584, Nov. 2020, doi: 10.1080/17408989.2020.1761953.

[9] S. Pill, B. SueSee, B. Hyndman, and J. Williams, "Physical education teachers' use of digital game design principles," $J$. Teach. Phys. Educ., vol. 40, no. 1, pp. 1-9, Jan. 2021, doi: 10.1123/JTPE.2019-0036.

[10] C. F. G. Farias, S. Harvey, P. A. Hastie, and I. M. R. Mesquita, "Effects of situational constraints on students' game-play development over three consecutive Sport 
Education seasons of invasion games," Phys. Educ. Sport Pedagog., vol. 24, no. 3, pp. 267-286, May 2019, doi: 10.1080/17408989.2019.1571184.

[11] A. Dellal, R. Jannault, M. Lopez-Segovia, and V. Pialoux, "Influence of the numbers of players in the heart rate responses of youth soccer players within 2 vs. 2,3 vs. 3 and 4 vs. 4 small-sided games," J. Hum. Kinet., vol. 28 , no. 1 , pp. 107-114, 2011, doi: 10.2478/v10078-011-0027-8.

[12]A. Casey and B. Dyson, "The implementation of models-based practice in physical education through action research," Eur. Phys. Educ. Rev., vol. 15, no. 2, pp. 175-199, Jun. 2009, doi: 10.1177/1356336X09345222.

[13] D. G. Slade, A. J. Martin, and G. Watson, "Developing a game and learning-centred flexible teaching model for transforming play," Phys. Educ. Sport Pedagog., vol. 24, no. 5, pp. 434-446, Sep. 2019, doi: 10.1080/17408989.2019.16 16684.

[14] A. Calderón and D. Tannehill, "Enacting a new curriculum models-based framework supported by digital technology within a learning community," Eur. Phys. Educ. Rev., p. 1356336X2096212, Oct. 2020, doi: 10.1177/1356336X2096 2126.

[15]M. K. Upadhyay and N. Nathani, "ROLE OF E-TECHNOLOGY IN PHYSICAL EDUCATION AND SPORTS.," Pharma Sci. Monit., vol. 6, no. 1, pp. 300-307, 2015.

[16] J. Ren, "Research on the Construction of Online and Offline Hybrid Individualized Teaching Model in Volleyball Courses," no. Emcs, pp. 664-667, 2018, doi: 10.25236/emcs.2018.165

[17] M. Lacome, B. M. Simpson, Y. Cholley, P. Lambert, and M. Buchheit, "Small-sided games in elite soccer: Does one size fit all?," Int. J. Sports Physiol. Perform., vol. 13, no. 5, pp. 568-576, May 2018, doi: 10.1123/ijspp.2017-0214.

[18] M. Aguiar, G. Botelho, C. Lago, V. MaçAs, and J. Sampaio, "A review on the effects of soccer small-sided games," $J$. Hum. Kinet., vol. 33, no. 1, pp. 103-113, 2012, doi: 10.2478/v10078-012-0049-x.
[19] I. Rocamora, S. González-Víllora, J. Fernández-Río, and N. M. Arias-Palencia, "Physical activity levels, game performance and friendship goals using two different pedagogical models: Sport Education and Direct Instruction," Phys. Educ. Sport Pedagog., vol. 24, no. 1, pp. 87-102, Jan. 2019, doi: 10.1080/17408989.2018.1561839.

[20] S. Stolz and S. Pill, "Teaching games and sport for understanding," Eur. Phys. Educ. Rev., vol. 20, no. 1, pp. 3671, Feb. 2014, doi: 10.1177/1356336X13496001.

[21]K. Jayantilal and N. O'Leary, “(Reinforcing) factors influencing a physical education teacher's use of the direct instruction model teaching games," Eur. Phys. Educ. Rev., vol. 23, no. 4, pp. 392-411, Nov. 2017, doi: $10.1177 / 1356336 \times 16652081$.

[22]A. Miller et al., "Can physical education and physical activity outcomes be developed simultaneously using a game-centered approach?," Eur. Phys. Educ. Rev., vol. 22, no. 1, pp. 113-133, Feb. 2016, doi: 10.1177/1356336X1559 4548 .

[23] N. M. Siregar, E. F. N. Sari, M. Budiningsih, and Zulham, "The basic learning model of traditional motion based games for early childhood (5-6) years," Int. J. Hum. Mov. Sport. Sci., vol. 9, no. 1, pp. 81-88, Jan. 2021, doi: 10.13189/saj.2021.090111.

[24] C. Fennell, E. L. Glickman, A. Lepp, J. D. Kingsley, and J. E. Barkley, "The Relationship between Cell Phone Use, Physical Activity, and Sedentary Behavior in United States Adults above College-age," Int. J. Hum. Mov. Sport. Sci., vol. 6, no. 4, pp. 63-70, 2018, doi: 10.13189/saj.2018.060401.

[25] B. Moy, I. Renshaw, and K. Davids, "Variations in acculturation and Australian physical education teacher education students' receptiveness to an alternative pedagogical approach to games teaching," Phys. Educ. Sport Pedagog., vol. 19, no. 4, pp. 349-369, 2014, doi: 10.1080/17408989.2013.780591.

[26] I. Kim and B. Ko, "Developing Elementary Content Knowledge in Physical Education Teacher Education," Int. J. Hum. Mov. Sport. Sci., vol. 4, no. 2, pp. 13-19, 2016, doi: 10.13189/saj.2016.040201. 